\title{
Kierownik na rozdrożu - uwagi wcale nie do śmiechu
}

https://doi.org/10.33141/po.2005.11.05

Stanisław Chełpa
Przegląd Organizacji, Nr 11 (790), 2005, ss. 20-22 www.przegladorganizacji.pl Towarzystwo Naukowe Organizacji i Kierownictwa (TNOiK)
„Wojna” i „walka” to pojęcia, które często i w sposób dość swawolny używane są do opisu rzeczywistości organizacji gospodarczych. Jeśliby te środki retoryczne miałyby być trafne, z jakimi może łączyć się to konsekwencjami? Stosowany przeze mnie tryb warunkowy, który należy określić jako gdybanie, jest celowy. Nie chcę bowiem formułować diagnoz, ani też wynikających z nich dyrektyw postępowania. „Diagnozy stawia się - jak twierdzi poeta A. Zagajewski, gdy się jest bardzo młodym i ambitnym, potem przychodzi czas już tylko na medytację i - co najwyżej - niepokój, któremu czasem towarzyszy coś w rodzaju chichotu" [21, s. 30]. Rozważmy więc wspólnie kilka kwestii ważnych dla „wojennych” zachowań kierowniczych.

1. Dla żołnierza, jak miał ponoć stwierdzić C. von Clausewitz, czasem normalnym jest wojna, czasem nienormalnym - pokój. Kogo jednak obchodzą żołnierze? Może ministra obrony narodowej. Kierowników to już raczej nie dotyczy. Tymczasem normalność i powszechność „cywilnej” wojny zakładali w swoich poglądach T. Kotarbiński (zob. [22]), J. Rudniański [14] i M. Ossowska [12]. Wcześniej, bo już w XVII wieku, uczynił to T. Hobbes [5, s. 110 i n.], pisząc o „wojnie każdego z wszystkimi innymi”. Napędzać ją miał - wymagający okiełznania - ludzki egocentryzm, wyrażany zwykle dążeniami do zdobycia indywidualnej mocy. Interesująco na ten temat wypowiadał się też H. Elzenberg [3, s. 417]. Stwierdził on mianowicie, że „między człowiekiem a człowiekiem jedyny stosunek w pełni rzetelny, to stosunek antagonizmu". Prawdziwość relacji interpersonalnych miałby więc gwarantować nieustający konflikt i ścieranie się racji. Czy stan ten nie burzyłby delikatnej materii, jaka jest synergia organizacyjna? A w związku z tym, czy może harmonizacja relacji wewnątrz organizacji (a także jej stosunków z otoczeniem) nie wymaga pewnej koniecznej dozy fałszu?

2. Na wojnie (i w miłości) wszystkie chwyty są dozwolone - mówi popularne porzekadło. W XVI w. o celu uświęcającym zastosowane środki pisał N. Machiavelli [9]. Podstęp jako kardynalną cnotę „wojenną” wskazywał wspominany tu już T. Hobbes [5, s. 112]. Wynika stąd, że pilność celów, ich waga i wielkość, a także, jak pokazuje historia, duże prawdopodobieństwo odniesienia zwycięstwa, mogą być traktowane jako wystarczające uzasadnienia zastosowanych środków działania. Przeciwnego zdania był T. Kotarbiński (cyt. za: [14, s. 152]), który stwierdził, że „w sytuacji, gdy cel uświęca środki - środki «uświńcają» cel”. Wydaje się więc, że nawet najbardziej zbożne ideały można zbrukać, zmierzając do ich osiągnięcia za pomocą nieodpowiednich metod. Być może warto przed podjęciem określonych działań rozważyć jeden z imperatywów kategorycznych sformułowanych przez I. Kanta [6, s. 46]. Brzmi on następująco: „Postępuj tak, byś człowieczeństwo tak w swej osobie, jako też w osobie każdego innego używał zawsze zarazem jako celu, nigdy tylko jako środka". Według tego nakazu moralnego, który miałby być normą powszechną, człowiek jawi się jako cel działań własnych i bliźnich. Zalecenie to, jak się zdaje, bywa jednak czasem swoiście pojmowane. Świadczy o tym zarówno praktyka, jak i literatura, w szczególności typu poradnikowego (zob. [15, 16, 17, 20]). Inna osoba bywa celem, tyle tylko, że wrogim. Celem, który chce się przede wszystkim zniszczyć. Nawiązując do cytowanej maksymy Kanta można zadać sobie następujące pytania. Po pierwsze, czy przejawianie agresji wobec innego, nie będzie jednocześnie aktem przyzwolenia na zachowania agresywne z jego strony? A po wtóre, czy działająca jak bumerang agresja nie jest po prostu autodestrukcją?

3. Najważniejszy jest człowiek. Zawsze on stoi bowiem w obliczu wyboru zarówno celów działania, jak i metod ich osiągania. Podkreśla to wielu badaczy. Jeden z nich, czołowy przedstawiciel inżynierii społecznej (behawioryzmu), B.F. Skinner [19, s. 170] twierdził, że metody „są w sensie moralnym obojętne; może się nimi posługiwać i łajdak, i święty”. Tak więc siekiera sama w sobie nigdy nie jest ani zła, ani dobra. Może nią posłużyć się stolarz, szykujący nowy stół i krzesła. Ale może też trafić w ręce jakiegoś nawiedzonego Raskolnikowa, chcącego przeprowadzić swe ambitne i wydumane zamiary. Nie siekiera, a system wartości działającego musi podlegać bezwzględ- 
nej ocenie. To niemodne dziś stwierdzenie zdaje się wspierać P.F. Drucker [2, s. 101], który pisząc o prawości charakteru stwierdził, że „nie ma nic bardziej demoralizującego i destruktywnego dla organizacji niż silny, ale gruntownie zdeprawowany menedżer (...). Można by go nawet tolerować, ale pozbawionego wszelkiej władzy nad innymi”. Jak widać kontrola taka, a w razie potrzeby stanowcze działania kadrowe maja uzasadnienie praktyczne. Stanowią także - zdaniem K. Poppera (cyt. za: [7]) - podwaliny ustroju demokratycznego.

4. „Problem uczciwości - jak trafnie zauważa K. Obuchowski, istnieje tylko wówczas, gdy osoba może kontrolować swoje odruchy, gdy zdolna jest do refleksji” [11, s. 54]. Namysł nad własnym działaniem dokonywany przed jego podjęciem lub post factum wyznacza decyzje o samoograniczaniu się człowieka. Jest to mniej lub bardziej, ale zawsze suwerenny akt wyboru. Najlepszą formą kontroli własnych pragnień i wszczynanych działań byłaby więc autokontrola. Podróż w głąb siebie i weryfikacja osobistych mniemań jest - jak się wydaje - ważna również z innego powodu. Wyraźnie wskazuje go H. Elzenberg [3, s. 63]. Stwierdził on mianowicie, że „cały rozwój człowieka polega na nieustannym sądzeniu siebie”.

5. Żeby działający podmiot mógł się efektywnie samooceniać, powinien on przyjąć jakiś układ odniesienia, z którym będzie mógł skonfrontować podjęte przez siebie cele zadaniowe i użyte sposoby dochodzenia do nich. Takim standardem potencjalnie możliwym do zaakceptowania przez kadrę kierowniczą współczesnych organizacji gospodarczych wydaje się średniowieczny etos rycerski. Może brzmi to staroświecko i co najmniej dziwnie, jednak pogląd taki znajduje jawnych zwolenników. Należą do nich M. Ossowska [12], P. Paliwoda [13] oraz R. Legutko [8]. Także C. Sikor-

\section{Tab. Najważniejsze zasady kodeksu rycerskiego}

- wierność podjętym zobowiązaniom i lojalność,

- podejmowanie działań w słusznej sprawie,

- poszukiwanie zadań będących wyzwaniem i chęć wyróżniania się,

- odwaga i gotowość przyjęcia odpowiedzialności za skutki podejmowanych działań,

- traktowanie przeciwnika z szacunkiem, jako równego sobie,

- unikanie podczas walki wszelkiej krzywdy niekoniecznej,

- uczciwe prowadzenie walki, bez uciekania się do podstępu i przebiegłości,

- podejmowanie walki z przeciwnikami silniejszymi lub równymi sobie,

- wspaniałomyślność wobec pokonanych, bez ich poniżania i wywyższania się.

Źródło: opracowanie własne na podstawie [1, 12, 22]. ski w swojej najnowszej książce [18] - choć ani razu nawet nie wspomina o rycerzach i obowiązujacym ich kodeksie - wydaje się podzielać to stanowisko. Zręby zasad rycerskiego postępowania zostały zaprezentowane w tabeli.

Odnosząc się do danych tabelarycznych należy stwierdzić, że przyjęcie postawy rycerskości i konsekwentne przestrzeganie jej zasad w zachowaniach zadaniowych może utrudnić osiągnięcie zaplanowanych celów. Nie można bowiem stosować wszystkich możliwych i dostępnych środków prowadzących do sukcesu. „O chwale rycerza - jak twierdzi M. Ossowska, decydowało nie tyle zwycięstwo, ile to, jak walczył" [12, s. 77]. Na styl działania, a nie jedynie na jego wynik, zwracał również uwagę H. Elzenberg [3]. Wybitny jego uczeń, który wolał filozofię przeżywać, a nie jak kwoka wysiadywać ją, namawiał, by do oceny poczynań ludzkich przykładać kryteria estetyczne [4]. W ten sposób podejmowane działania mogą być nie tylko skuteczne, ale też eleganckie. Najprostszym, ale i chyba najskuteczniejszym miernikiem tego ostatniego może być czucie trzewiowe, objawiające się naturalnym fizjologicznym odruchem typu zemdli czy też nie. Za reakcje fizjologiczne (własne i cudze) kierownik nie będzie jednak nagradzany. Biznes to nie romans, liczą się w nim skuteczność i efekty ekonomiczne. Z tego punktu widzenia trzymanie się zasad rycerskich wydaje się mieć sens. Nie daje to może spektakularnych i szybko osiaganych zysków, ale opłaca się w dłuższej perspektywie czasowej. Wynika to stąd, że buduje się pozytywny wizerunek (jaźń odzwierciedlona) w bliższym i dalszym otoczeniu. Ponadto, kształtowane są, na zasadzie wzajemności, korzystne relacje z innymi. Dodać tu koniecznie trzeba, że zasady opisywanego kodeksu miały niegdyś obowiązywać jedynie wśród rycerzy. Zachowania wobec ludzi spoza tego stanu nie krępowały już prawie żadne reguły, a na pewno były poza kodeksem rycerskim. Współczesny kierownik staje więc $\mathrm{w}$ obliczu pytania, kto jest mu równy i przysługuje mu rycerskie traktowanie. Czy pracownicy na przykład są dla niego partnerami. Czy też może stanowią, co prawda, konieczny zasób organizacji, ale za to niezbyt rozwinięty pod względem świadomościowym, kierujący się w swym postępowaniu elementarnymi potrzebami, będący przeszkodą, którą trzeba za wszelką cenę pokonać, w szczególności w sytuacji wprowadzania zmian organizacyjnych. I co z tego, że zmiany te mają poprawić kondycję organizacji, zapewnić jej przetrwanie i dać szansę rozwoju, a w konsekwencji polepszyć sytuację pracowników właśnie. Elita organizacyjna to rozumie (bez zbędnych słów). A masy członkowskie. Czy są w stanie to pojąć i w sposób dojrzały (dorosły) odejść od swych partykularnych i doraźnych interesów. Przed kierownikiem staje też inna kwestia. Musi rozstrzygnąć, co robić w przypadku zetknięcia się z przeciwnikiem nie przestrzegającym żadnych reguł organizacyjnego fair play. „Niezależnie od tego, jak postępuje nieprzyjaciel - twierdzi gen. J. Fuller, bardziej opłaca się walczyć jak gentleman, aniżeli jak nikczemnik, bowiem nikczemna wojna może się skończyć tylko nikczem- 
nym pokojem, taki zaś pokój - jeszcze jedną wojną" (cyt. za: [22, s. 41]). Nie wiadomo jednak, czy ta generalska rada ma znamiona uniwersalności. Czy sztywne jej przestrzeganie nie będzie przyczyną własnej klęski. Może rozważając ten dylemat warto pamiętać o haśle oświeceniowym z okresu rewolucji francuskiej, tworzącym przecież europejską tradycję, do której dziś niektórzy tak chętnie się odwołują. W pełnym brzmieniu - o czym przypomina K. Mroziewicz [10, s. 11] szło ono następująco: „Wolność, równość, braterstwo albo śmierć".

dr hab. Stanistaw Chetpa

Katedra Zarządzania Kadrami Akademii Ekonomicznej we Wrocławiu

\section{BIBLIOGRAFIA}

[1] BARBER R., Rycerze i rycerskość, Dom Wydawniczy Bellona, Warszawa 2003.

[2] DRUCKER P.F., Menedżer skuteczny, Czytelnik i Wydawnictwo Akademii Ekonomicznej, Kraków 1994.

[3] ELZENBERG H., Ktopot $z$ istnieniem. Aforyzmy $w$ porzadku czasu, Wydawnictwo Uniwersytetu Mikołaja Kopernika, Toruń 2002.

[4] HERBERT Z., ELZENBERG H., Korespondencja, Wydawnictwo Fundacji Zeszytów Literackich, Warszawa 2002. [5] HOBBES T., Lewiatan czyli materia, forma i władza państwa kościelnego $i$ świeckiego, PWN, Warszawa 1954.

[6] KANT I., Uzasadnienie metafizyki moralności, Wydawnictwo Antyk, Kęty 2001.

[7] KONOPKO M., Czy Karl Popper byt wrogiem społeczeństwa otwartego, „Fronda”, 2001, 25/ 26.

[8] LEGUTKO R., Złośliwe demony, Wydawnictwo Stalky \& Co., Kraków 1999.

[9] MACHIAVELLI N., Ksiażę. Rozważania nad pierwszym dziesięcioksięgiem historii Rzymu Liwiusza, PIW, Warszawa 1984.

[10] MROZIEWICZ K., Caty strach świata (wywiad przeprowadzony przez M. Świętochowicz), „Angora”, 2005, 30.

[11] OBUCHOWSKI K., Cztowiek intencjonalny, Wydawnictwo Naukowe PWN, Warszawa 1993.

[12] OSSOWSKA M., Ethos rycerski i jego odmiany, PWN, Warszawa 1986.

[13] PALIWODA P., Zapach synów Allaha, „Ozon”, 2005, 18.

[14] RUDNIAŃSKI J., Kompromis i walka. Sprawność i etyka kooperacji pozytywnej $i$ negatywnej $w$ gęstym otoczeniu spotecznym, Instytut Wydawniczy Pax, Warszawa 1989.

[15] SANTORO V., Jak wrobić wrednego szefa, Wydawnictwo Książki Niezwykłej XXL, Wrocław 2005.

[16] SANTORO V., Osaczanie, czyli jak doprowadzić wrogów do szaleństwa, Wydawnictwo Liberator, Wrocław (bez roku wydania).

[17] SCHRIJVERS J.P.M., Poradnik korporacyjnego szczura. Podręcznik przetrwania dla politykujacych $w$ firmie i na urzędzie, Wydawnictwo Helion, Gliwice 2005.

[18] SIKORSKI C., Język konfliktu. Kultura komunikacji społecznej w organizacji, C.H. Beck, Warszawa 2005.

[19] SKINNER B.F.,Poza wolnościa i godnościa, PIW, Warszawa 1978.

[20] V., Menedżer jak mafioso, Wydawnictwo Studio Emka, Warszawa 1996.

[21] ZAGAJEWSKI A., Obrona żarliwości, Wydawnictwo a5, Kraków 2003.

[22] ZAKRZEWSKI L.S., Ethos rycerski $w$ dawnej i wspótczesnej wojnie, Wydawnictwo Trio, Warszawa 2004. 